\title{
TRAUMA AS CHANCE AND CHALLENGE: HOW TO DRAW BENEFIT FROM MEMORIZED CHILD EXPERIENCES IN WORLD WAR II
}

\author{
Geert Franzenburg \\ University of Muenster, Germany \\ E-mail: franzenburg@t-online.de
}

\begin{abstract}
Re-experiencing of traumatic memories becomes a social core-phenomenon concerning people of advanced age, and, thus, a core-challenge for coping-strategies. Therefore, adult educators and counselors are looking for an appropriate approach how to help their clients coping with such memories successfully. This study aims to demonstrate one possible approach based on religious coping and on the evaluation of published memories of elder German people (Dierig, 2012; Jakobi \& Link, 1997), who remember their childhood shortly after World War II. It also evaluates published studies about this issue concerning their contribution to educational and/or counseling purposes. One main aspect is the comparison between the deferring, collaborative, and self-directing style of religious coping (Pargament, 1997), compared with secular analogies. Another aspect concerns the question, whether religious people are primary intrinsic or extrinsic oriented. In order to find out, why people prefer a particular strategy, an elementary form of grounded theory is chosen, which facilitates particular key categories and terms. The study does neither intend any own empirical research, nor evaluating therapeutic issues, because it is done from a German educational and counseling point of view. Thus, it emphasizes the religious, psychological, and cultural aspects of experiences and coping-strategies of people, who experienced War and post-war time as children in Germany, or of children expelled from Eastern Europe .
\end{abstract}

Key words: child memories, coping strategies, grounded theory, traumatic war experiences.

\section{Introduction}

Although a documentation of the children of World War II and their story, which documents injuries, and explores their coping mechanisms is just in the beginning, as well as an evaluation and research on their traumata (Bohleber, 2006; Leuzinger-Bohleber, 2006), the number of memoirs of former War-children is increasing, which facilitated research on developmental and contextual aspects of trauma-coping (Hagen \& Ronge, 1962; Henlein, 2011). Therefore, this study supplements former studies, which explored the long term effects of war trauma on the physical and mental health of former children of War, particular interdisciplinary longitudinal studies (Schmitt, 2007; Stargardt, 2005). 


\section{Problem of Research}

Because remembering childhood includes narrations, rituals and symbols, coping with traumatic or at least strange childhood experiences, is a kind of religious coping, often in a more secular form. Therefore, concerning the issue of German War-children, particular religious aspects of this process become important, when rituals, narrations and symbols are taken into account, which work with the emotional aspects of coping. (Corsini, 2009; Pargament, 1997). In this context, the "skeptical generation", born between 1925 and 1935, which means without significant participation in the Nazi regime, but influenced by their youth organizations (Schelsky, 1957), is a core sample for such research, because these people suffered as children from War and postwar situations. Therefore, they need help for coping with such challenges by facilitating an atmosphere of basic trust and by facilitating religious and secular multidimensional strategies during the process of coping with challenging memories.

\section{Research Focus}

Concerning the mentioned observations and considerations, evaluating the experiences of former war-children, particularly their adoption to German post-war society, is the chance and challenge to widen the repertoire of coping strategies. Coping with their traumata, former children of war often adopted Nazi education and war virtues, such as harshness or tenacity, as copingstrategies, in order to become harder (Grundmann, Hoffmeister, Knoth, 2009; Kiess et al., 2014).

At the same time the answers show the tendency of religious coping by narrations, rituals and symbols, because of the core trauma of missing basic trust. Therefore, people often became unable to show emotions (Naechster, 2014) Thus, the study will answer the following questions:

1. How do German adults remember their childhood shortly after World War II?

2. How did they cope with strange or traumatic experiences?

3. Which role did religious beliefs and attitudes play in their coping strategies?

4. Are there any influences on these strategies to be seen (gender, context)?

5. How can these strategies be transferred into analogue current situations in an educational or counseling way?

\section{Methodology of Research}

\section{General Background of Research}

In order to find out how adult educators and counselors can help their clients coping with postwar child experiences, particular strategies and approaches of religious coping (deferring, collaborative and self-directing, either intrinsic or extrinsic motivated) should be evaluated by analyzing published memories (interviews) of elder German people according to the model of grounded theory. The key categories and terms demonstrate, why and how different persons are coping in different situations; thus, these results explain the core challenges of coping, and allow to transfer them into educational or counseling frameworks and methods (biographical work, creative sharing, and others). The self-directed, deferring, and collaborative style of religious coping (Pargament et al. 1988) are helpful categories for both, evaluating and facilitating alternative approaches. The self-directing style reflects the belief that God has little direct influence in the lives of individuals; therefore it is the individual's responsibility to solve problems for themselves. Conversely, the deferring style emphasizes the choice to wait for God to directly intervene in human affairs to provide a solution to the presenting problem. The collaborative coping style involves a decision to share responsibility with God for solving the problem. Pargament (1997) posits that these religious coping strategies can be categorized into general positive and negative constructs, based in part on typical outcomes (Pargament,et al.,1998), particularly concerning attachment and emotion regulation (Corsini, 2009). 
The research is limited to a sample of 16 exemplary chosen extracts from published interviews (7 female, 9 male), which are drawn from collections with interviews with Germans, who remember their time during and after the war in Muenster (Dierig, 2012; Jakobi \& Link, 1997). It is, therefore, also limited on the German context, and of a particular population (born between 1925 and 1935).

\section{Instrument and Procedures}

Grounded theory as an instructional inductive approach of data collection and evaluating (Strauss \& Corbin, 1994) uses participants' experiences as data to construct and validate the emergent theory or set of theories. Therefore, it is an appropriate approach for comparing data material with existing theories by open coding, memo making, and sampling (Glaser, 1978; Glaser, 1994). Following the key words and key categories of the published interviews, more general phenomena, concepts, and core categories can be found during the process of comparison and abstraction at a theoretical level (Glaser \& Strauss, 1967; Spiggle, 1994). In this approach, the core categories are a central account for a large proportion of behaviour, based on recurring themes drawn from the data, related meaningfully to other categories, and a modifiable starting point for analysis (Glaser, 1978).

\section{Data Analysis}

The following tables underline the role of multidisciplinary approaches (1) and coping strategies (2) for evaluating the process of remembrance

Table 1. Theories.

\begin{tabular}{|c|c|c|c|c|c|}
\hline Approach & Education & Counseling & Theology & History & Methodology \\
\hline Purposes & $\begin{array}{l}\text { Human ind./soc. } \\
\text { Development }\end{array}$ & Trauma-Coping & Reason/Sense & Remembrance & Grounded Theory \\
\hline Literature & $\begin{array}{l}\text { Bandura (1986) } \\
\text { Bird\&Reese } \\
\text { (1996) } \\
\text { Bronfenbrenner } \\
(1979)\end{array}$ & $\begin{array}{l}\text { Bohleber (2006) } \\
\text { Boothby (1992) } \\
\text { Forstmeier et al. } \\
(2009) \\
\text { Glaesmer et al. } \\
(2012) \\
\text { Grundmann et al. } \\
\text { (2009) } \\
\text { Kuwert et al. } \\
\text { (2008) } \\
\text { Leuzinger-Bohleber } \\
\text { (2006) } \\
\text { Radebold (2006) } \\
\text { Riedesser }(2006) \\
\text { Schmitt (2007) } \\
\text { Werner(2007;2012) }\end{array}$ & $\begin{array}{l}\text { Frankl (1963 and } \\
1975) \\
\text { Hathaway \& } \\
\text { Pargament } \\
\text { (1990) } \\
\text { Naechster } \\
\text { (2014) } \\
\text { Pargament } \\
\text { (1997) } \\
\text { Pargament, et al. } \\
\text { (1998) } \\
\text { Pargament\& Abu } \\
\text { Raiya (2007) }\end{array}$ & $\begin{array}{l}\text { Dierig (2012) } \\
\text { Henlein (2011) } \\
\text { Hagen\&Ronge } \\
\text { (1962) } \\
\text { Jacobi\&Link } \\
(1997) \\
\text { Kiess et al. } \\
(2014) \\
\text { Schelsky (1967) } \\
\text { Stargardt (2005) }\end{array}$ & $\begin{array}{l}\text { Camahalan } \\
(2014) \\
\text { Glaser } \\
(1978 ; 1994) \\
\text { Glaser\&Strauss } \\
(1967) \\
\text { Strauss\&Corbin } \\
(1994)\end{array}$ \\
\hline
\end{tabular}

Table 2. Data sample.

\begin{tabular}{|c|c|c|c|c|c|}
\hline \multirow{2}{*}{ Category } & \multicolumn{2}{|c|}{ Religious coping } & \multicolumn{2}{|c|}{ Secular coping } & \multirow{2}{*}{$\begin{array}{c}\text { Comments } \\
\text { Symbols/rituals }\end{array}$} \\
\hline & Internal & external & Individual & Social & \\
\hline Food /hunger & Prayer (f) & $\begin{array}{l}\text { Songs (f) } \\
\text { sharing (f) }\end{array}$ & $\begin{array}{l}\text { Irony (f) } \\
\text { long walk (m) }\end{array}$ & $\begin{array}{l}\text { Empathy (f) } \\
\text { Duty (m) } \\
\text { control }(\mathrm{m})\end{array}$ & $\begin{array}{l}\text { Food ration cards } \\
\text { cleaning streets } \\
\text { potatoes }\end{array}$ \\
\hline
\end{tabular}


OF PSYCHOLOGY

IN THE $21^{\text {st }}$ CENTURY

Vol. 10, No. 1, 2016

16

\begin{tabular}{|c|c|c|c|c|c|}
\hline \multirow{2}{*}{ Category } & \multicolumn{2}{|c|}{ Religious coping } & \multicolumn{2}{|c|}{ Secular coping } & \multirow{2}{*}{$\begin{array}{c}\text { Comments } \\
\text { Symbols/rituals }\end{array}$} \\
\hline & Internal & external & Individual & Social & \\
\hline School/learning & $\begin{array}{l}\text { Forced prayer } \\
\text { instead of Nazi ritual } \\
(\mathrm{m}) \\
\text { authority model }(\mathrm{m})\end{array}$ & Community (f) & $\begin{array}{l}\text { Adventure (m) } \\
\text { missing mate- } \\
\text { rial/history- } \\
\text { lessons (f) } \\
\text { missing school } \\
\text { - job (m) } \\
\text { missing sport- } \\
\text { lessons (m) }\end{array}$ & $\begin{array}{l}\text { Mixed groups (f) } \\
\text { value of meals (f) }\end{array}$ & Books, paper, food \\
\hline Family/home & $\begin{array}{l}\text { Eternal love for } \\
\text { homeland (m) }\end{array}$ & $\begin{array}{l}\text { (grand)parents } \\
\text { as models/care } \\
\text { relatives first }\end{array}$ & $\begin{array}{l}\text { Suffering (f) } \\
\text { Anger (f) } \\
\text { Saving (m) }\end{array}$ & $\begin{array}{l}\text { Thank (f) } \\
\text { belongings (m) }\end{array}$ & $\begin{array}{l}\text { House/flat } \\
\text { furniture }\end{array}$ \\
\hline Church/religion & $\begin{array}{l}\text { Ind. Responsibility } \\
\text { for parish life (f) } \\
\text { bible study (f) } \\
\text { pastor as model (m) }\end{array}$ & $\begin{array}{l}\text { Common rooms } \\
\text { for both groups } \\
\text { (Cath,/prot.) (m) } \\
\text { no clergy Com- } \\
\text { munity (f) } \\
\text { parish home (m) }\end{array}$ & $\begin{array}{l}\text { Feeling as a } \\
\text { stranger ( } f \text { ) }\end{array}$ & $\begin{array}{l}\text { Duty (key/ prepara- } \\
\text { tion) (f) } \\
\text { (prot.) discrimina- } \\
\text { tion (m/f) }\end{array}$ & Altar, church-room \\
\hline $\begin{array}{l}\text { Political } \\
\text { changes }\end{array}$ & $\begin{array}{l}\text { No sin } \\
\text { (late birth) }\end{array}$ & $\begin{array}{l}\text { Sincerity (f) } \\
\text { tradition (f) }\end{array}$ & $\begin{array}{l}\text { Anger (m) } \\
\text { skepticism (f) }\end{array}$ & $\begin{array}{l}\text { Duty }(m) \\
\text { responsibility }(m) \\
\text { no privileges }(f)\end{array}$ & $\begin{array}{l}\text { De-nacification } \\
\text { questionnaires }\end{array}$ \\
\hline $\begin{array}{l}\text { Economical } \\
\text { changes }\end{array}$ & New start (f/m) & Church fashion & $\begin{array}{l}\text { New shoes (f) } \\
\text { new job }(m)\end{array}$ & $\begin{array}{l}\text { Member of society } \\
(\mathrm{f} / \mathrm{m})\end{array}$ & New currency \\
\hline
\end{tabular}

Note: $(m=$ male, $f=$ female $)$

\section{Results of Research}

The evaluation of the answers facilitates the following answers to the research questions:

\section{How do German adults remember their childhood during and shortly after World War II?}

They mainly remember particular key categories, which are recognized in the published interviews. These categories are specified by particular key terms, which depend on remembering rituals or symbols: When remembering suffering from hunger, they preferably remember - similar to family life - the general organization of food supply (cards, weight, control). When remembering school life, they mostly remember the lack of books, material, knowledge, lessons, but also food supply and mixed classes, which underline their particular "hunger" for learning. When remembering family and home, they emphasize on the core function of family as authority for traditions, values, care and home, particular in traumatic situations (suffering). When remembering church life, they show similar attitudes by emphasizing community, and suggesting one's own responsibility for a fruitful encounter and community. When remembering changes in postwar society, they emphasize rituals and symbols (questionnaire, new currency), and underline their intention to become an appropriate member of the new society.

These observations underline that during the process of remembrance both perspectives are mixed: the adult remembering one, and the remembered child perspective. The emphasis on both, individual responsibility and social duties, furthermore, underline the multidimensional character of remembrance

\section{How do they cope with strange or traumatic experiences?}

Depending on the situation, the respondents prefer either religious - concerning church issues - or secular coping strategies - concerning everyday issues; mostly, however, their attitude can be interpreted both way, because the particular situation of War and postwar times combined both implications: the longing for sense, coherence, transcendence, and the need to organize and 
improvise. Their answers illustrate that everyday life implied, on one hand, a particular spirituality, which was not church oriented (empathy, short prayer, sharing rituals, songs, but, on the other Vol. 10, No. 1, 2016 hand, a very pragmatic style of church life (preparing, caring for services in school and other secular rooms, joke about forced prayer in school, laicist communities). In all cases, secular and religious, rituals and symbols are mentioned, such as long way walking, encounters, answering questions; cards, food, furniture, rooms.

\section{Which role do religious beliefs and attitudes play in their coping strategies?}

Considering these observations, remembering childhood, concerning this particular historical German context, means facilitating a kind of "secular religiousness", which helps to combine transcendent and immanent purposes. Therefore, the individual and social dimension (intrinsic and extrinsic religiousness) are combined similar to the secular context (value - faith, society parish). While male answers more incline to a self-directing style, female ones prefer a deferring or at least collaborative style (Pargament, 1997).

\section{Are they any influences on these strategies (gender, context)?}

It became obvious that male respondent prefer more active attitudes of change, while female ones emphasize on empathy, emotions and suffering. Another impact comes from the family, which is a core element of their coping strategies, either as guarantee of tradition, as caregiver or symbol of home. In the second place of authorities as models are clergy and teachers. Another context is the particular memory-culture, which influence the kind of remembrance, such as the change from a fascist towards a democratic society, or from an intact to a partial family structure.

\section{How can these strategies be transferred into analogue current situations in an educational or} counseling way?

The evaluated multidimensional character of remembrance, which combines the individual with the social aspect, the particular historical situation with a general message for current and future analogue situations, suggests a multidimensional approach concerning the consequences and adaptations, by applying theological and historical approaches on the counseling and/or educational situation.

Concerning educational situations and purposes, such as encouraging personal development by biographical work, sharing of past experiences and considering them, the strong bond between the primary caregiver and the child, the availability of additional caregivers, the social support of members in the community who are exposed to the same hardships, especially teachers and peers, can be used to facilitate a common value system (shared sense of values, a religious belief that finds meaning in suffering, the assumption of responsibility for the protection and welfare of others), which can become a kind of defense-mechanism, and, thus, facilitate resilience (Werner, 2007). Religion becomes involved in such coping processes, when children encounter problems that impinge on something that is important or significant to him or her (Pargament, 1997), such as hunger of food, learning, chances or other kinds of suffering during and after the War.

Another crucial concept to draw benefit from the emphasis on authorities and models, is the phenomenon of reciprocal determinism (Bandura, 1986), which underlines that a person's religious coping cognitions are present as a result of the triadic, bidirectional interactions among and between the (religious) coping behaviour of a person and others (e.g. parents and peers) in his or her environment. Therefore, such person is learning his/her coping strategy by observing the behaviour of others (Bandura, 1986), as exemplified by the role of authority models (parents, teachers, pastors) in the answers. As applied to religious coping, when the observed behaviours are religious in nature, the observer forms religious cognitions and symbols that represent his or her developing repertoire of religious thoughts, beliefs, feelings, and judgments about the observed religious behaviour, the situation, and the environment, in which it occurred. These are cognitively stored as an option for religious coping at a later time, vicariously encoded as symbols and cognitions (Bandura, 1986). Related to religious coping, there are observed risks and benefits of behaviour, too: the age, sex, 
OF PSYCHOLOGY IN THE $21^{\text {st }}$ CENTURY Vol. 10, No. 1, 2016

race, and background of the model, similarities to the model, and the degree, to which the model is admired, particular concerning parents and close friends.

Concerning counseling purposes and situations, such as resilience training or case work with traumatic situations, the particular "secular religiousness" and the balancing between individual responsibility and traditional value systems, as emphasized in the answers, is crucial: Besides of the mentioned considerations and concepts, both underline the role of creativity and of a sense of coherence and meaning for counseling and trauma coping purposes.

That the answers emphasize experiencing, which facilitates creative, attitudinal or transcendent values within human freedom, reminds of the model of logo-therapy as a further core approach for such contexts, because becoming responsible for and finding meaning and reason within one's life are core-purposes of people suffering from victim experiences; in such situations, conscience as referring to a real person in a real situation can facilitate faith, hope, and love by filling an existential vacuum (Frankl,1975).

\section{Discussion}

Concerning the issue of German children of war, as already mentioned in the introduction, the "skeptical generation" (Schelsky, 1957), which most of the respondents are part of, is a core sample for such research, because, as the answers underline, the particular changes of family, political, and social changes they remember, became core challenges in their life, exemplified by post-traumatic ego-syntonic symptoms, such as panic, depression, weak (gender-) identity (Radebold, 2006; Riedesser, 2006). An appropriate answer could be, as the answers show, an atmosphere of basic trust and the opportunity of multidimensional coping strategies with the long-term consequences of war. Concerning educational and counseling contexts and purposes, such approach should be aware of negative patterns of religious coping, which suggest a sense of insecurity in relation to God, such as spiritual discontent, punishing God or demonic reappraisal (Pargament et al., 1998). Therefore, it should include also theological and historical aspects of remembrance and coping, and concern people "secular religiousness", their search for personal meaning (Frankl,1963). Religiousness and spirituality, thus, represent potentially valuable resources for individuals in counseling.

What individuals remember during childhood years is mostly an explanation of causes and influences in regard to their present adult life (Bird \& Reese, 2006). Therefore, coping theory represents one promising perspective from which to understand, study, and work with religious issues (Pargament, 1997), because perceived coping self-efficacy emerges as a focal mediator of post-traumatic recovery (Benight \& Bandura, 2004).

Because childhood experiences are remembered as emotional triggers (Scott, 2004), they can illustrate how events in children's life are interconnected, and demonstrate how early experiences may impact adult life (Renk et al, 2005; Bronfenbrenner, 1979).

In using grounded theory for finding key terms and categories, such aspects of influences become obvious, and facilitate opportunities for creative and multidimensional coping, because they are interwoven into every aspect of narratives and attitudes (Camahalan, 2014).

As exemplified by the evaluated interviews, stories of childhood memories, it illustrates two major types of coping strategies, cognition and affect. Therefore, one way to find meaning and a sense of coherence within one's biography in both way, cognitive and emotionally, is becoming aware of one's spiritual needs: If people consider their own experiences as a war-child, they emphasize secular and religious aspects of trauma and of coping strategies, such as trust, solidarity, and care, in a holistic coping model. Such attitude of value-oriented remembrance prevents from refuge into just adventurous war stories, which lead horror, fear and panic into nightmares. It also prevents from the separation between narratives and emotions, particularly, when combined with media-information, which become part of one's remembrance, and, thus, a crucial issue for further research (Radebold, 2006). 


\section{Conclusions}

Because positive coping beliefs improve positive mood, and lower distress religiousness as a particular search for significance and meaning can become a core aspect of resilience; therefore, religious pathways can be manifested through multiple dimensions in which the sacred is involved, such as ideology, ethical conduct, emotional experience, social intercourse, and study, particularly, when religious coping is concerned (secular religiousness). Thus, within the answers, God is mentioned in an indirect manner as the experience of basic trust and of being cared, balancing between one's own responsibility and fate orientation.

Regarding the evaluated particular situation of children of war and their experiences, religious oriented coping strategies (dream, ritual, believes, trust) are fully embodied in the individual's life and in situations, which push beyond everyday understandings and limited personal and social resources. Thus, in War-traumata during childhood, people draw on religious solutions to problems from a more general orienting system by evaluating their own and other beliefs, practices, attitudes, goals, and values. Therefore, religious coping methods are concrete manifestations of religion in difficult times and stressful situations, and a complex, multifaceted phenomenon with multi-dimensional implications. People, when remembering traumatic childhood experiences, should, therefore, integrate it with their needs, goals, situations, and social context, preferably with professional helpers, who appreciate and encourage the individual religious (positive and negative) coping-resources, particular concerning meaning in life, theodicee, and spiritual connectedness with others. Therefore, researchers have to get in contact with live experiences: They talk to people, get to know them, learn about their lives and faiths, and follow their concerns and difficulties over times; thus, they become able to deepen their knowledge, and to gain empathy, particular concerning the wounded inner child, Grounded theory can be a substitute, when memoirs only are available in written or transcript form, particular concerning child experiences. Thus, this research concerning a short particular sample and situation should invite to make own experiences with such multidimensional approach towards educational, counseling, theological and historical aspects of remembrance and coping.

\section{References}

Bandura, A. (1986). Social foundations of thought and action: A social cognitive theory. Englewood Cliffs.

Bird, A., \& Reese, E. (1996). Emotional reminiscing and the development of an autobiographical self. Developmental Psychology, 42 (4), 613-626.

Bohleber, W. (2006). Kriegskindheiten und ihre lebenslangen seelischen Folgen (childhood sin war and their life-long consequences). In: Radebold, H. Heuft, G., Fooken, I. (Hg.) Kindheiten im Zweiten Welt- krieg. Kriegserfahrungen und deren Folgen aus psychohistorischer Perspektive [Childhoods in World War II. War experiences and their consequences from a psycho-historic point of view]. Weinheim, 51-60.

Boothby, N. (1992). Displaced children: Psychological theory and practice from the field. Journal of Refugee Studies, 5 (2), 106-122.

Bronfenbrenner, U. (1979). The ecology of human development, Harvard MA.

Camahalan, F. M. G. (2014). Recalling childhood memories: An instructional approach using grounded theory. Journal of Instructional Pedagogies, 14, 1-14.

Corsini, K. D. (2009). Examining the relationship between religious coping strategies, attachment beliefs and emotion regulation in a mixed sample of college students attending an evangelical University in Central Virginia." Unpublished Doctor of Philosophy Dissertation, Liberty University, March, 2009 (retr. http://digitalcommons.liberty.edu/doctoral/270/ (19.3.2016).

Dierig, H. (2012). Der leidvolle Weg zu einem neuen Zuhause [The painfull way towards new home]. Münster.

Forstmeier, S., Kuwert, P., Spitzer, C., Freyberger, H. J., \& Maerckler, A., (2009). Postraumatic growth, social acknowledgment as survivors, and a sense of coherence in former German child soldiers of World War II. American Journal of Geriatric Psychiatry, 17, 1030-1038. 
Frankl, V. E. (1963). Man's search for meaning: An introduction to logotherapy. NewYork.

Frankl, V. E. (1975). The Unconscious God: Psychotherapy and theology. New York.

Glaesmer, H., Kaiser, M., Freyberger, H. J., Brähler, E., \& Kuwert, P. (2012). Die Kinder des Zweiten Weltkrieges in Deutschland: Ein Rahmenmodell für die psychosoziale Forschung [The children of World War II in Germany: A model for psycho-social research]. Trauma \&Gewalt, 6 (4), 318-328.

Glaser, B. G. (1978). Theoretical sensitivity: Advances in the methodology of grounded theory. Mill Valley, Ca.

Glaser, B. G. (Ed.) (1994). More grounded theory methodology: A reader. Mill Valley, Ca.

Glaser, B. G., Strauss, A. L. (1967). The discovery of grounded theory: Strategies for qualitative research. Chicago.

Grundmann, M. Hoffmeister, D., Knoth, S. (Hg.) (2009). Kriegskinder in Deutschland zwischen Trauma und Normalität. Botschaften einer beschädigten Generation [Children of War in Germany between trauma and normal life. Messages of a wounded generation]. Münster.

Hagen, W., Thomae, H., Ronge, A. (1962). 10 Jahre Nachkriegskinder. Ergebnisse und Dokumente [Ten years of Post War children. Results and documents]. Oxford.

Hathaway, W. L., \& Pargament, K. I. (1990). Intrinsic religiousness, religious coping, and psychosocial competence: A covariance structure analysis. Journal for the Scientific Study of Religion, 29, 423-441.

Henlein, M. (2011). Das Trauma der deutschen Kriegskinder zwischen nationaler und europäischer Erinnerung: Kritische Anmerkungen zum gegenwärtigen Wandel der Erinnerungskultur [Trauma of German war-children between national and european remembrance. Critical remarks on current chances of memory culture]. In: Narratives of Trauma: Discourses of German Wartime Suffering in National and International Perspective. Eds. Helmut Schmitz and Annette Seidel-Arpaci. German Monitor 73. Amsterdam, 111-128.

Kiess, J., Decker, D., Grave, T., Rothe, K, Weißmann, M., Brähler, E. (2014). Erinnertes elterliches Erziehungsverhalten und politische Einstellungen in den Generationen des Zweiten Weltkriegs und der Nachkriegszeit - Ergebnisse der ,Mitte-Studien“(Memorized parent-education and political attitudes of the generations of World War II and Postwar times. Results of “Mitte” studies). In: Fooken, I., Heuft, G. (Hg.) (2014). Das späte Echo von Kriegskindheiten. Die Folgen des Zweiten Weltkriegs in Lebensverläufen und Zeitgeschichte, Göttingen, 147-179.

Kuwert, P., Spitzer, C., Dudeck, M., Vogel, M., Freyberger, H. J., \& Ermann, H. (2008). Psychological complaints, interpersonal problems, quality of life and sense of coherence in former German war children. Psychotherapie, Psychosomatik und Medizinische Psychologie, 58, 257-263.

Leuzinger-Bohleber, Marianne (2006). Kriegskindheiten, ihre lebenslangen Folgen - dargestellt an einigen Beispielen aus der DPV-Katamnesestudie [War childhoods and their life-long consequences, demonstrated by examples from the DPV “Katamnese” study]. In: Radebold, H., Heuft, G., Fooken, I. (Hg.) (2006). Kindheiten im Zweiten Weltkrieg. Kriegserfahrungen und deren Folgen aus psycho-historischer Perspektive [Childhoods in World War II. War experiences and their consequences from a psycho-historic point of view]. Weinheim, 61-82.

Jakobi, F. J., Link, R. (1997). Geschichte im Gesprach: Kriegsende 1945 und Nachkriegszeit in Münster [History in dialogue. End of War 1945 and Postwar times in Muenster]. Muenster.

Naechster, K. (2014). Verdeckte Spuren des Krieges - Beobachtungen einer Krankenhausseelsorgerin [Hidden traces of War - observations of a clinical femal pastor]. In: Fooken, Insa, Heuft, Gereon, (Hg.) (2014), Das späte Echo von Kriegskindheiten. Die Folgen des Zweiten Weltkriegs in Lebensverläufen und Zeitgeschichte [The late echo of War childhoods. The consequences of World War II in biographies and in current history]. Göttingen, 213-229.

Pargament, K. I. (1997). The psychology of religion and coping: Theory, research, practice. New York.

Pargament, K. I., Smith, B. W., Koenig, H. G., \& Perez, L. (1998). Patterns of positive and negative religious coping with major life stressors. Journal for the Scientific Study of Religion, 37 (4), 711-725.

Pargament, K. I., Abu Raiya, H. (2007). A decade of research on the psychology of religion and coping: Things we assumed and lessons we learned. Psyke \& Logos, 28, 742-766. 
Radebold, H. (2006). Kriegskindheiten in Deutschland - damals und heute [War childhoods in Germany -then and today]. In: Radebold, H. Heuft, G., Fooken, I. (Hg.) (2006), Kindheiten im Zweiten Weltkrieg. Kriegserfahrungen und deren Folgen aus psychohistorischer Perspektive [Childhoods in World War II. War experiences and their consequences from a psycho-historic point of view]. Weinheim, 15-26.

Riedesser, P. (2006). Belastende Kriegserfahrungen in der Kleinkindzeit [Traumatic war experiences in early childhood]. In: Radebold, H. Heuft, G., Fooken, I. (Hg.), Kindheiten im Zweiten Weltkrieg. Kriegserfahrungen und deren Folgen aus psychohistorischer Perspektive [Childhoods in World War II. War experiences and their consequences from a psycho-historic point of view]. Weinheim, 37-50.

Schelsky, H. (1957). Die skeptische Generation. Eine Soziologie der deutschen Jugend [The skeptical generation. A sociology of german youth]. Düsseldorf.

Schmitt, M. (2007). Interdisziplinäre Längsschnittstudie des Erwachsenenalters: Folgen kollektiver Kriegstraumata im Erwachsenenalter [Interdisciplinary longtime-study of adult age: Consequences of collective war traumata in advanced age]. In: Fooken, I. \& Zinnecker, J. (Hg.), Trauma und Resilienz [Trauma and resilience]. München, 109-120.

Stargardt, N. (2005). Witnesses of War: Children's Lives under the Nazis. London.

Strauss, A., \& Corbin, J (1994). Grounded theory methodology: An overview, In N. K. Denzin \& Y. S. Lincoln (Eds.), Handbook of qualitative research (pp. 273-285). Thousand Oaks, CA: Sage.

Werner, E. E. (2012). Children and war: Risk, resilience, and recovery. Development and Psychopathology, $24,553-558$.

Werner, E. E. (2007). Resilience and protective factors in the lives of individuals who were children and youths in World War II. In: Fooken I., Zinnecker, J. (Eds.), Trauma und Resilienz [Trauma and resilience]. München, 47-55.

Advised by Guna Svence, Riga Teacher Training and Educational Management Academy, Latvia 